\title{
LEGAL PROTECTION OF NEW PLANT VARIETIES IN THE REPUBLIC OF SERBIA
}

\author{
Nadežda Ljubojev ${ }^{1}$, Marïana Dukić Mijatović², Željko Vojinovič̉
}

\begin{abstract}
The protection of new plant varieties as a form of intellectual property is generally accepted. It is a sui generis legal protection which, in the framework of industrial property rights, creates new, distinctive, stable and homogeneous plant varieties, marked with a variety label, but there is also a tendency of patent protection in the world. The basic features of this legal protection are exclusivity and autonomy in relation to the legal regime established for the placing of planting material in commercial traffic. The aim of this paper is to examine the legal implications and to answer certain issues concerning the protection of intellectual property in this area. The historical-legal and normative-legal method for the consideration of the historical development of the legal protection of plant breeders and the analysis of positive law in this area in the Republic of Serbia were used in the framework of the harmonization of rights with international law and the law of the European Union.
\end{abstract}

Key words: protection, plant varieties, sui generis, patent law, Republic of Serbia.

JEL: $Q 17, K 11$

\section{Introduction}

Providing sufficient amounts of food is an effort whose biological, economic and social significance are manifested at all levels of human existence, starting from an individual, over families and other social groups to the social community as a whole, regardless of geographical area and at all times.Considering the number of population and reducing of

1 Nadezda Ljubojev Ph.D., Associate Professor, University of Novi Sad, Technical Faculty "Mihajlo Pupin”, Đure Đaković street nn, 23000 Zrenjanin, Republic of Serbia, Phone: +381 23550520 , E-mail: nadezdaljubojev@gmail.com.

2 Marijana Dukić-Mijatović Ph.D., Full Professor, University of Business Academy, Law Faculty of Economics and Justice, Novi Sad, and University Novi Sad, Faculty of Economy in Subotica, Segedinski put no. 9-11 24000 Subotica, Republic of Serbia, Phone: +38163542093, E-mail: marijana.dukic.mijatovic@gmail.com

3 ŽeljkoVojinović Ph.D., Assistant professor, University Novi Sad, Faculty of Economy in Subotica, Segedinski put no. 9-11 24000 Subotica, Republic of Serbia, Phone: +381 6488326 00, E-mail: zv@inbajmok.com.

EP 2017 (64) 3 (1191-1204) 
arable land dueto pollution, construction, and so on, this is becoming increasingly important technological, economic legal and social-political issue. In this regard, the aim of this paper is to consider legal protection for creators of new, and more resistant plants in the Republic of Serbia (RS). The basic methods of work are historical-legal and normative-legal. The historical development of the egal protection of plant breeders is analyzed, as well as the positive law in this area.

Ever since human has been dealing with agriculture, he has tried to reach new abounding and resistant plant varieties. With the advancement of science and technology and increased level of knowledge, a large number of new plant varieties has been created. In theory, plant variety is defined "as a group of herbaceous plants of common origin, which are different from related plants after their hereditary characteristics impotent for the needs of forestry, horticulture and agriculture" (Marković, 1997a). Creation of new plant varieties is a long and complex process which entails great effort, knowledge and financial investments. For the creating of new plant varieties there are needed scientific knowledge in the fields of genetics, plant breeding, molecular biology biometrics, as well as the extensive experience and overall intellectual knowledge of the creators of new plant varieties (Veselinović et al., 2014).

For centuries, man has created new plant varieties. Plant varieties are produced by plant breeding ${ }^{4}$ which can be performed by classical methods and genetic engineering, which creates the desired properties of living organisms at the genes level. The once produced plant variety needs to be maintained. Due to the risk of degeneration of self-spreading plant varieties, the purity and health of generative reproductive material (seeds) must be constantly monitored. Maintenance of this type of plant varieties is done by periodic repetition of the key stages for the cultivation of the variety as well as permanent selection. Varieties of plants that are cross-fertilized are not capable of self-reproduction. This is why a breeder needs to maintain inbreeding line year after year and repeat the hybridization process (Ljubojev, Varga, 2012). This means that "plant varieties are maintained as the variety does not exist in cases where it is not possible to obtain a second, $\mathrm{n}^{\text {th }}$ generation of plants characterized by varietal-specific properties (Marković, 2000).

Inclusion into international and regional economic flows is not possible without regulating the issue of protection of all forms of intellectual property. At the Sixth Intergovernmental Conference in Luxemburg, in June 2017, within the framework of the accession of negotiations with the European Union (EU), the RS opened Chapter 7 on the protection of intellectual property. The platform for negotiations of the opening of this chapter includes "the harmonization of legislation with EU legislation which does not only imply the amendment and implementation of laws, but also the implementation involving judicial protection."

4 Breeding, which is being performed increasingly intensively, with the application of new technologies, shortens an average age of the variety used, especially in vegetable plant species and ornamental one-year herbs. The number of varieties reported rapidly increases, while the average lifespan decreases (Milošević, 2012)

5 "EurActiv RS", www.euractiv.rs/pregovori-sa-eu/10930-priprema-se-pregovaraka-platforma-zapoglavlje-7. 


\section{Protection regime for plant breeders in the framework of intellectual property rights}

Accelerated growth in agricultural production is the result of an increasing number of inventions and new achievements in science. In theory, the reason for the approach to the creation of plant is that "new plant varieties, with higher yields, improved quality or better resistance to pests or diseases can increase productivity and product quality in agriculture, horticulture and forestry" (Idris, 2003). For millenniums, humanity passed through the process of selecting plants to create populations that fit its needs (Milošević, 2012). However, as already mentioned, the creating of new plant varieties requires significant investment in the form of knowledge, labor and material resources. It also requires time and the creating of plant variety is a long-standing process that can last for more than a decade. It usually takes more than ten years to use a new plant variety to compensate for the cost of its creating and its legal protection (Veselinović, Milošević, 2012). However, once created, the plant variety (depending on the type) can be reproduced immediately, (Bently, Sherman, 2004) which deprives the breeder of the variety of the opportunity to recover the investment and to benefit from the use and disposal of the created plant variety. In order to prevent the unauthorized reproduction of the plant variety and its placing on the market, the plant breeder must be provided with legal protection. In this way they are stimulated to intensify the work on the creation of new plant varieties, which directly stimulates the development of agriculture and improves the production of food and raw materials. The state's interest is to encourage breeders to intellectual creativity in the field of the emergence of new better varieties. Producers of plant varieties as a general matter must have the same rights to exclude unauthorized use for making, using, offering for sale and selling or importing for those purposes as do other inventors (Lesser, 2004). The aim of legal protection of new plant varieties is promoting the development of improved plant varieties for the benefit of farmers, growers and consumers. However, if it is used without an permit, the overall multidisciplinary results are questionable. It should also be noted that the use of a protected variety for non-commercial and scientific research purposes, including use for breeding new varieties, is not required by the holder of the rights.

The production of new plant varieties is highly desirable. Namely, as the creating of a plant variety is an intellectual creative work, it is quite certain that the notion of a plant variety is "logical abstraction in relation to the plant species that make up the variety. Herbal individuals concretize the variety, that is, they represent corpus mechanicum of the breed (Marković, 2000).Thus, the plant variety appears as a guide to the process of creating herbal individuals with specific characteristics for the purpose of improving agriculture, horticulture and forestry. However, the fact that a plant variety is an intellectual property which can be applied in agriculture is not sufficient to establish protection for the creator of the plant breed by the right on industrial property. Not only the right to industrial property, but also the right to intellectual property; not all commercially usable products of human spirit are protected, but only those explicitly enumerated in the sources of intellectual property rights, that is, based on the principle of taxonomy (numerus clausus). According to the Article 27 of the Convention on Trade-Related Aspects of Intellectual Property Rights from 1995 (TRIPS), Member States are required to provide protection of plant varieties, whether by patients, 
by appropriate sui generis system, or by their combination, which makes the condition for establishment of protection of creators of herbal species within the rights of industrial property fulfilled. Therefore, TRIPS recognizes the specificity of the protection of plant varieties. In view of the above, it can be concluded that in the legal theory it is not disputed that creation of new varieties of agricultural plants "undoubtedly belongs to the field of industrial property" (Gajinov, 1996). However, the area of industrial property is broad and complex, so that, legally, it is possible to observe several legal regimes of legal protection for the creators of new plant varieties.

\section{Legal and historical development}

The first institutions involved in controlling and improving the quality of reproductive plant material were founded in the 19th century. Until the beginning of the 20th century, the activities within these institutions were outside the state control, and the production and trade of seed and planting material were completely free. Over time, governments recognized the importance of the work of the institutions to provide enough food for the population, as well as for the development of agriculture and the economy in general. Therefore, production and trade in reproductive material began to be regulated by the law. In legal theory, it is considered that the meaning of these legal regulations, which exists today in all the countries of the world, is to ensure that in market traffic and use for the purpose of sowing and planting, only the reproduction material found on the basis of the previous mandatory control is found as good and suitable for local climatic, land and other conditions. (Marković, 2000). The breeders whose plant varieties met the legally determined cond0ntegral part of our law, since the Law on the Recognition of a European Patent was adopted. Although in the EU new plants cannot be protected by the patent itself, there are exceptions. A plant that has a specific gene (unlike its entire genome) is not included in the definition of a plant variety, and can therefore be protected by a patent. Likewise, genetically modified plants can be patented in the EU, unless they are limited to a particular plant variety but represent a larger group of plants.European Directive 98/44/EC considers plant cells as microbiological products, and as a result, they can be patented.

\section{The International Convention for the protection of new varieties of plants}

Due to the great economic significance of the creation of new plant varieties and the impossibility of their patenting, a sui generis protection system was created, which is not a patent protection, but a form of legal protection. Actually, in the late fifties of the last century it was certain that there were no conditions for the protection of plant species to be institutionalized in the patent protection system. Therefore, at the initiative of French government, in 1957, there was started diplomatic and expert work on the drafting of an international convention, which would regulate protection of a new plant variety. The 
International Union for the Protection of New Varieties of Plants (UPOV) ${ }^{6}$ was established by the International Convention for the Protection of New Varieties of Plants ("UPOV Convention"). The UPOV Convention was adopted on December 2, 1961, by a Diplomatic Conference held in Paris, and revised in 1972, 1978, and 1991. ${ }^{7}$ The UPOV Convention itself was amended in 1978 "in a way that allowed the US to come within its fold" (Cornish, Llewelyn, 2003), and then again in 1991. According to the UPOV Convention, the plant variety is designated as "a plant grouping within a single botanical taxon of the lowest rank", but this group, regardless of whether the conditions for granting the rights of breeders are fully met, can: a) be determined by research characteristics that are the result of a genotype or a combination of genotypes; $b$ ) be differentiated from any other group of plants by expressing at least one of the above characteristics; and c) be considered a unit with regards that its ability to reproduce is unchanged (Chapter I Definitions, Art. 1 Paragraph 1 (vi)). In order to obtain legal protection under the UPOV Convention, the plant variety must be: new, distinct, uniform, stable and marked with the appropriate name."A separate application must be filed to receive protection in each member country" (Jondle, 1989). According to Art.6, p. 1, the Law on the Ratification of an International Convention on the protection of new plant varieties, the variety is considered new if, on the day of application for the Protection of the Breeder's Rights, the reproductive or harvested material of that variety has not been sold or otherwise disposed of by the breeder or with his consent for the use of the given variety: a) in the territory of the Contracting Party to which a request for protection has been lodged for a period longer than one year before that date, and b) in the territory outside the territory of the Contracting Party to which the request for protection has been lodged for a period longer than four years before the application was submitted, and in the case of woody species and vines, over a period longer than six years before the specified date. Regarding the other conditions of legal protection of the plant variety, UPOV has developed a methodologyso-called DUS test (Distinctness, Uniformity, Stability test). (Marković, 1997b). A plant variety is distinct if it is "clearly distinguishable from any other variety whose existence is a matter of common knowledge at the time of the filing of the application" (UPOV, Art. 7). Distinctiveness may arise through visible differences in outward appearance, such as height, size of leaves, leaf color. It may also arise through physiological differences associated with the variety's particular chemical or biological structure, such as resistance to disease or ability to withstand certain conditions (Bentley, Sherman, 2004) (such as cold, drought or so). A variety is uniform "if subject to the variation that may be expected from the particular features

6 UPOV is an intergovernmental organization in the UN system, within the World Intellectual Property Organization (WIPO), based in Geneva. As a supreme body, the UPOV Council consists of representatives of all members of the UPOV, and each member state has one vote in the UPOV Council. The Acronym of the French Union name - Union internationale pour la protection des obtentions vegetales - UPOV - is its internationally accepted mark.

7 The UPOV Convention came into force on August 10, 1968, having been ratified by the United Kingdom, the Netherlands and Germany. The UPOV Convention has been revised on November 10 , 1972, on October 23, 1978, and on March 19, 1991, in order to reflect technological developments in plant breeding and experience acquired with the application of the UPOV Convention.http:// www.upov.int/upovlex/en/conventions/1991/w_up910_html\#_1.

EP 2017 (64) 3 (1191-1204) 
of its propagation, it is sufficiently uniform in its relevant characteristics." (UPOV Art. 8) "This means that nearly all examples of the variety must bear the characteristics that make the plant distinct" (Bentley, Sherman, 2004). It does not mean that all plants in a variety are exactly alike genetically (Bliss, 1989). Uniformity is reached when the proportion of deviation in a breeding procedure has been reduced to a point beyond which it would be unreasonable to expect further experimentation" (Cornish, Llewelyn, 2003). A plant variety is stable if its relevant characteristics remain unchanged after repeated propagation or, in the case of a particular cycle of propagation, at the end of each such cycle (UPOV, Art. 9). "The aim of testing stability is to determine that subsequent generations of the plant are not throwing up noticeably more deviation" (Cornish, Llewelyn, 2003). By recognized rights, the titularies get entitled to: production or reproduction of plant variety, reprocessing, offering for sale, sale or other type of marketing, export, import, storage for any of the aforesaid purposes.

UPOV Convention stipulates the subject of protection, the conditions of protection and the duration of protection. It also performed "the emancipation of the right of varietal protection from the influence of national regulations on the control of the production and trade of reproductive material of plant varieties" (Marković, 2000). As we pointed out, the UPOV Convention has established the right of varietal protection as a sui generis industrial property right. It is precisely this sui generis system that relates to Article 27 of the TRIPS Agreement. Therefore, although the plant variety is excluded from patent protection, it is protected by the sui generis of the right plant variety (in accordance with UPOV) or a combination of UPOV sui generis plant protection and patent protection system. ${ }^{8}$ Most countries select pure plant breeders' right option (Lesser, 2004). However, the plant variety as a group of herbal individuals is excluded from patent protection, but it is therefore possible to patent inventions related to the genome of plants, plant organs or plant parts (Brush, 1996). This means that products of the plant or their reproductive material (seeds, roots, seedlings, etc.) can be patented, but those in which the plant variety is not specified, as well as the inventions of products related to other botanical material (e.g. cell lines, modified cells, genes, etc.) that cannot be regenerated in the plant (Marković, 1997). Accordingly, the invention of all plant material which is not characterized by the belonging of a plant variety can be protected by a patent. In this respect, the exclusion from patent protection does not include those inventions of the biotechnological procedure relating to the plant (or animal), if the technical feasibility of the invention is not limited to a particular plant variety (or animal race). This practically means that the patent application will not be rejected in cases where the plant variety is

8 As an example, In USA, where in addition to the patent for plant varieties propagated by vegetative pathway (the so-called plant-patent), the Plant Protection Law of 1970 established a system of varietal protection, although patent protection of plant varieties in the USA cannot be said to be a classic patent. It is only nominally a patent, because in terms of content, according to the patent for the plant, in terms of content the titulary has narrower rights than the holder of a classic patent for inventions (Barton, 1993). 
not explicitly specified in the patent application ${ }^{9}$ (Wilson, 2005), as well as when more than one plant variety is covered by the patent application (Bentley, Sherman, 2004). ${ }^{10}$ Our legislator took over the patent protection model from the UPOV Convention. EPC has similar provisions. In theory, it is considered that "our legislator, in one instance, deviates from the sui generis protection of new plant varieties and establishes patent protection". Actually, the Law on the Protection of Plant Breeders in Article 31 provides for a mandatory license, in the event that the carrier of rights of breeders refuses to grant other persons the right to use the protected plant variety or poses unjustified conditions for such a transfer. As the license and license agreement is a legal institute of patent law, it is evident that our legislator has "crossed "the border" of sui generis protection" (Veselinović, Milošević, 2013).

The emergence of modern technologies, especially biotechnology, puts many challenges ahead of the legislator in the normative regulation of the protection of these rights. Apart from domestic legislation, it is a significant source of rights in this field and ratified international treaties for the Republic of Serbia.

\section{The procedure to exercise right to plant breed in the Republic of Serbia}

For many years, RS has achieved the best results in the placement of intellectual property in the world by creating new varieties of agricultural plants. In this sense, Gajinov states that in the Scientific Institute of Field and Vegetable Crops in Novi Sad, the largest scientific institution in the field of biotechnological sciences in our country, since its establishment in 1938, more than 600 new varieties of agricultural plants have been created. By planting seeds of protected plant species created at the Institute, an economic effect has been achieved, which is measured by hundreds of millions of US dollars. Over 1000 new plant varieties have been created and recognized in the RS (Gajinov, 1996). Therefore, legal regulation of this area in our law was necessary, both from the point of view of our breeders, and on the legal safety of foreign breeders, who would like to place their varieties on our market. This certainly applies to our agricultural producers, seed companies, plant breeders, state institutions and the state as a whole. Sui generis legal protection of plant breeders is provided both at international and national level. It has already been said that at the international level legal protection of plant breeders is ensured by the UPOV Convention, although the importance of TRIPS from 1995 should not be ignored. At the beginning of 2013, RS became the $71^{\text {st }}$ UPOV member. As a necessary prerequisite, the RS fully harmonized its legislation and the system of protection of the rights of plant breeders with the UPOV Convention by adoption of the Law on the Protection of Plant Breeders (2009) (LPBPV), the Law on the Confirmation of the Convention on the Protection of New Plant Varieties (2010) and Law on Amendments to the Law on the Protection of Plant Breeders (2011). It is a sui generis legal protection

9 For example, the patent application for the grant of a patent for Triticummonococcum (wheat variety) will be rejected, while the invention of the technology applicable to the whole genus Triticum will not be considered an invention in respect of which patent protection is excluded, and in this case the patent claim will be acceptable.

10 The authors refer to the case of Novartis/Transgenic Plant, T 1054/96 [1999] EPOR 123, 137 (TBA).

EP 2017 (64) 3 (1191-1204) 
that, under industrial property rights, creates new, distinctive, stable and homogeneous plant varieties marked with a variety label.The basic features of this legal protection are exclusivity, temporality and autonomy in relation to the legal regime established for the placing of planting material in commercial traffic.

By joining the UPOV, Member States have the opportunity to participate and use the experiences of other countries through UPOV membership, to intensify cooperation between Member States for the examination of plant varieties, where one member country accepts the results of the examination of varieties of other member states as the basis for granting of breeding right. In this way, the costs of functioning of the protection system are reduced, and the breeders are allowed to protect their varieties in other countries at lower costs and in that way realize the possibility of wider placement of their seed and planting material on the foreign market. Membership in UPOV should have an impact on all entities in this area, as well as on the state as a whole, in terms of regulating the issue of protection of intellectual property in all spheres." Membership should contribute to increasing the market competitiveness of domestic products on the world market, using a large number of new protected varieties, which are characterized by better production and technological properties, higher yields, more resistant to diseases and pests, which will enable better plant production. ${ }^{11}$

The most significant source of legal regulation of this field in Serbia is the Law on Protection of Breeders of Plant Varieties, (LPBPV). An integral part of the Serbian legal system is also the UPOV Convention, passed by UPOV, ratified by the RS in 2010, as well as the International Treaty on Plant and Genetic Resources for Food and Agriculture, ratified in the 2013.This is the normative protection in this domain of intellectual property, while the issue of the implementation of the adopted laws remains. The Regulation of the European Council (REC) created a system for the protection of plant varieties as one and only form of industrial property rights for new plant varieties in the EU, managed by The Community Plant Variety Office - CPVO. CPVO seat is in Angers, France. EU Member States have a unique system of legal protection of plant varieties by Council Regulation (EC) No. 2100 from 1994 on the communal law of varietal protection. The Community Protection System managed by the CPVO provides added value so that breeders can receive return on investment in the EU territory. To date, the highest number of requests relates to ornamental species (about 60\%), followed by agricultural species $( \pm 20 \%)$ and fruits and vegetables $( \pm 20 \%)$. Each year more than 2800 requests are examined, making this system the most comprehensive system of its kind in the world. Requests are generally accepted from EU countries. Approximately 20\% of the requests come from countries outside the EU. ${ }^{12}$

Historically, in our country the procedure for the recognition of new plant varieties was prescribed by the Law on Recognition of newly established, approval of introduction into the

11 Views on the official website of the Ministry of Agriculture.

12 The Community Plant Variety Office - CPVO. "Protectionof new plant varieties in Europe, http:// cpvo.europa.eu/sites/default/files/documents/brochures/Brochure HR.pdf. 
production of foreign and protection of varieties of agricultural and forest plants. ${ }^{13}$ The 1980 Law was not harmonized with the UPOV Convention, the TRIPS and the EU regulations, and in 1998 the Law on the Recognition of Agricultural and Forestry Varieties and the Law on the Protection of Varieties of Agricultural and Forestry Plants were adopted in 2000. ${ }^{14}$ The separation of the two legal matters that were made by the adoption of these laws was completely justified because the control of production and trade of reproductive material and varietal protection yields different interests and therefore the conditions for recognition from one and protection of the plant variety on the other hand do not have to coincide (Ljubojev, Varga, 2012). The law on protection of the rights of plant breeders from 2010, as amended in 2011 , is a positive law on the basis of which sui generis legal protection is provided for the new plant variety.

Protected plant variety is that plant variety that is protected under the provisions of the law that regulates the protection of the new plant variety sui generis with the right on industrial property. Plant variety rights arise as a result of a process of registration (Bently, Sherman, 2004). The legal protection of the plant variety is provided by the ministry competent for agriculture in legal proceedings. The procedure is initiated at the request of the plant breeder, or his authorized representative. Upon receipt of the request, it is approached to examine the fulfillment of formal conditions for the recognition of rights.In the framework of the examination of the regularity of the Request, it is particularly examined whether the conditions for the entry of the application for the exercise of the breeder's rights and the proposed variety name into the Registry of Requests, and in particular whether the conditions for the adoption of the proposal for the variety's name have been fulfilled. The conditions for registering the request and the proposed variety name in the Register of Requests are fulfilled if the submitted documentation is complete and if it is made in accordance with the law. However, if not, the Ministry will, with a statement of the reasons, invite the breeder or his authorized representative to remedy the deficiencies within 30 days from the date of receipt of the notice. If the deficiencies are not timely removed, the Minister will reject the request with a conclusion. Upon registration of the request in the Register of Requests, it is checked whether the conditions for the recognition of the variety's name have been fulfilled. After the proposal of the variety name is accepted, it is accessed by substantive examination of the request. The fulfillment of material conditions for the recognition of the rights of plant breeders is determined by a solution. The solution is based on the results of the examination

13 The characteristic of this law was the condition of varietal protection by the prior acknowledgment of the new domestic variety, ie the approval for introduction into the production of a foreign variety. It was only by enrolling the plant variety in the register of recognized varieties for domestic, that is, in the register - for foreign varieties, at the request of the authorized person, the right of varietal protection could be obtained under the additional condition that it is possible to undoubtedly carry out the identification of the variety whose legal protection is required.

14 In the meantime, this area has been normatively expanded by the adoption of the Law on Reproductive Material of Forest Trees, (Official Gazette of RS, No. 135, 2004), the Law on Fruit, Vine and Honey Planting Material, (Official Gazette of RS, No. 18, 2000) And the Law on Seeds (Official Gazette of the Republic of Serbia, No. 45, 2005).

EP 2017 (64) 3 (1191-1204) 
and the proposal of the Expert Council.Until a decision is made, any person who believes that the variety is not new, different, uniform and stable, or that the breeder does not belong to the breeder's right, may, from the date of publication of the application for the grant of the plant variety breeder's right, file an objection to the entry of the application into the Registry of Requests. The complaint can also be submitted in relation to the proposed variety name. The complaint is submitted within three months from the date of publication of the proposal for the variety name.This objection must be provided to the applicant for an answer. The deadline for reply is 30 days and within that period the applicant may also propose another name for the variety, either on their own initiative or at the request of the Ministry. It must be acted according to the order of the Ministry, otherwise the request is rejected with the conclusion. The variety for which the breeder is granted the right of plant breeders to be registered shall be entered in the Register of protected plant species at the Ministry of Agriculture, and the list of protected plant varieties with data shall be published in the "Official Gazette of the Republic of Serbia". The right of the breeder to the protected plant variety lasts for 25 years, and for potatoes, vineyards, woody fruits and other trees 30 years from the date of recognition of the right, which is the day of issuing a decision on the approval of the breeder's request (Article 23, paragraph 1). The holder of the breeder's right may transfer his right of breeder in respect of a protected variety, in whole or in part, by contract to another person. This contract is mandatory in writing. The right of the breeder can also be transferred to another person on the basis of the license agreement. Civic and legal protection of the breeder's rights is provided with two lawsuits: a lawsuit for violation of the breeder's rights and a lawsuit for determining the rights of breeders.

Sui generis protection of plant varieties is our legal framework for exercising intellectual property in this area, although there are tendencies in the world to protect right with a patent. The protection of plant varieties as intellectual property has a special significance for our agriculture because the multi-year multidisciplinary work for the creation of a new plant variety can be successfully completed only when the creators get the status of the breeder. The international agreement on plant genetic resources for food and agriculture, "which Serbia adopted, has also endangered the breeder's rights in Serbia", because although there is a normative framework in the RS for the protection of new plant varieties, the largest number of plant varieties in our country are not protected as intellectual property (Veselinović et al. 2014). On the other hand, the Agreement provides the possibility for individuals and legal entities from other signatory countries to use the new plant varieties of our breeders. Since plant varieties are not protected, there is a possibility of endangering the breeder's rights. 
Also, the breeder's rights may be limited by a "farmers' privilege" ${ }^{15}$ It is therefore of great importance for our breeders to protect as many plant varieties as possible in the coming period, so that the varieties would not be unauthorizedly used or protected from illegal holders.

\section{Conclusion}

The right of industrial property ensures an extremely high degree of legal protection that owners of not all, but only those intellectual creations applicable in performing commercial (and agricultural) activities that are considered as industrial property, can enjoy. In this sense, the connection of plant varieties and (field) economic activity is not difficult to notice. The precondition concerning the intellectual character is fulfilled because the plant varieties are considered materialization of the intellectual, ie, biotechnological work on the creation of a plant variety. Given that fruit and seed material is res in commercio, this precondition is fulfilled. According to TRIPS, it is explicitly stipulated that the Member States (WTO) are obliged to provide patent, sui generis, or combined legal protection to the producers of plant varieties, and in terms of the possibility of protecting holders of plant varieties, the precondition of a formal nature is therefore fulfilled. Accordingly, all the preconditions for the property interests of plant breeders to be protected are protected within the framework of industrial property rights, but not by the patent law. A new plant variety cannot be portrayed as an invention of the patent law. The main reason is that herbal individuals belonging to the plant variety cannot naturally reproduce so that without the intervention of a man during the unlimited number of reproduction cycles they retain the characteristics of the variety. This means that the instruction on the creation of a plant variety is not sufficient for the average agricultural engineer to create a given plant variety. No legal protection under the rights of the trademark or under the rules on the suppression of unfair competition is inappropriate because it is subsidiary to the system of legal control of the marketing of seed and propagating material. The protection of property interests of plant varieties producers in relation to competitors and the protection of the public interest in providing planting materials that meet the prescribed quality and health standards are two, by their very nature, different objectives, and unique legal regulation cannot be adequate. The provision of the sui generis legal protection of plant breeders is generally accepted as a way of regulation that can be achieved at this moment within the framework of industrial property law. Sui generis system of legal protection of holders of new plant varieties in our law implies not only special sources of rights, but also organizational peculiarity, since the tasks of application of the laws within this specific biotechnological legal matter are entrusted to the Ministry of Agriculture, and not to the patent, that is, to the office for intellectual property. However, there is a need for

15 The "Farmers privilege" is a legal option for a farmer to re-use the seed of a protected variety, although it is protected as an intellectual property. LPBPV as well as the UPOV Convention creates a privilege or legal exception" (Veselinović, Milosević, 2013). In theory, it is considered: "Farmer is allowed to do something beyond the basic rules of protection of the variety as an intellectual property. However, the UPOV Convention guarantees certain exclusive rights to planting material, so farmers are often forced to commit to the contract not to use seeds produced on their property for seeding the following year" (Šarac, 2006). The same author believes that "farmers are hindered from using 'farmer's privileges' this way".

EP 2017 (64) 3 (1191-1204) 
adequate legal protection of plant varieties, bearing in mind the fact that our breeders have so far managed to protect less than $1 \%$ of plant varieties as intellectual property. While the protection of plant varieties in developed countries is almost absolute.

\section{Literature}

1. Bainbridge, D. (2007): Intellectual Property, Pearson Education Limited, Harlow.

2. Barton, J. H. (1993): Adapting the Intellectual Property System to New Technologies in: Intellectual Property Rights in Science and Technology, National Academy Press Washington, pp. 256-283.

3. Bentle, L., Sherman, B. (2004): Intellectual Property Law, Oxford University Press, Oxford and New York.

4. Bliss, F. A. (1989): Plant Breeding, Crop Cultivars and the Nature of Genetic Variability, in: Intellectual Property Rights Associated with Plants, Madison: Crop Science Society of America, American Society of Agronomy. Soil Sci. Soc. Am. pp. 69-89.

5. Brush, S. B. (1996): Whose Knowledge, Whose Genes, Whose Rights? in: Valuing Local Knowledge: Indigenous People and Intellectual Property Rights, Island Press Washington. pp. 1-21.

6. Cornish W., Llewelyn, D. (2003): Intellectual Property: Patents, Copyright, Trade Marks, and Allied Rights, Sweet \& Maxwell, London, United Kingdom.

7. Council Regulation No. 2100/94 on Communitary Plant Variety Rights (1994), OJL 132, 2. 11. 1994., available at: www.wipo.int/edocs/lexdocs/laws/en/ee/ee119en.pdf.

8. Directive 98/44/EC of the European Parlament and of the Council of 6 July 1998 on the legal protection of biotechnological inventions, Official Journal of the European Communities L 213/13, available at: http://eur-lex.europa.eu/legal content/HR/ TXT/?uri=CELEX\%3A31998L0044)

9. Fowler, C., (2000): The Plant Patent Act of 1930: A Sociological History of its Creation.

10. Gajinov, T.(1996): Pravnirežimintlektualnesvojineustvaranjunovihsortipoljoprivrednog bilja - kritički osvrt na neka rešenja u legislativi, Pravni život, No. 11, pp. 881-890.

11. Hayman, E. A. (1962): Botanical Plant Patent Law, 11 Clev.-Marshall L. Rev. 430.

12. Idris, K. (2003): Intelektualna svojina - moćno sredstvo ekonomskog rasta, AŠ delo, Beograd.

13. Jondle, R. J. (1989): Overview and Status of Plant Proprietary Rights in: Intellectual Property Rights Associated with Plants, pp. 5-15.Crop Science Society of America, Inc. American Society of Agronomy, Inc and Soil Science Society of America Madison.

14. Jovanović, S. (Zavod za intelektualnu svojinu R. Srbije) (2000): Zaštita intelektualne svojine u oblasti biotehnologije, u: Izbor objavljenih radova stručnjaka Zavoda 1920 -2000, No. 1, Beograd, Srbija, 157-173.

15.Lesser, W. (2004): An Economic Approach to Identifying an 'Effective Sui Generis System' for Plant Variety Protection under TRIPs in: Agriculture and Intellectual Property Rights: 
Economic, Institutional and Implementation Issues in Biotechnology, CABI Publishing Oxon, pp. 53-76.

16. Ljubojev, N., Varga, S. (2013): The Legal Protection of New Plant Varieties, African Jornal of Agricultural Research, Vol. 8, No. 16, pp. 1333-1339.

17. Marković, S. (1997a): Patentno pravo, Nomos, Beograd, Srbija.

18. Marković, S. (1997b): Harmonizacija jugoslovenskog prava sortne zaštite sa evropskom $i$ drugom međunarodnom regulativom, Pravni život, No. 11, pp. 753-764.

19. Marković, S. (Zavod za intelektualnu svojinu R. Srbije) (2000): Intelektualna svojina na biljnim sortama, Teslic M (ed) Izbor objavljenih radova stručnjaka Zavoda 1920-2000, No. 2, Beograd, Srbija. p. 79-101.

20. Međunarodna konvencija o zaštiti novih biljnih sorti (1961), UPOV, Pariz 1961, Ženeva 1972, 1978, 1991, Zakon o potvrđivanju međunarodne konvencije o zaštiti novih biljnih sorti, Službeni glasnik Republike Srbije, Međunarodni ugovori, No. 19, 2010.

21. Međunarodni ugovor o biljnim genetičkim resursima za hranu i poljoprivredu, Službeni glasnik Republike Srbije, Međunarodni ugovori, No. 1, 2013.

22. Milošević, M. (2012): Zaštita biljne sorte kao intelektualne svojine, Semenarska asocijacija Srbije, Novi Sad, Srbija.

23. Šarac, J. (2006): Specifičnosti zaštite prava intelektualne svojine u oblasti biotehnologija, Singidunum revija, Univerzitet Singidunum, Belgrade, Serbia, Vol. 8, No. 1, p. 355.

24. Veselinović, J., Milošević, M., Počuča, S., (2014): International Treaty on Plant Genetic Resources for Food and Agriculture as a Basis for Limiting Intellectual Property, Economics of Agricuture, IAE, Belgrade, Vol. 61, No. 1, pp. 211-223.

25. Verona, A. (1997): Zaštita izuma, Informator, Zagreb.

26. Williams, S. B. Jr, Weber, K, A. (1989): Intellectual Property Protection and Plants, in: Intellectual Property Rights Associated with Plants, pp. 91-107, Crop Science Society of America, American Society of Agronomy, Soil Science Society of America, Madison.

27. Wilson, C. (2005): Intellectual Property Law in a Nutshell, Sweet \& Maxwell,London, United Kigdom.

28. Zakon o priznavanju novostvorenih, odobravanju uvođenja u proizvodnju stranih i zaštiti sorti poljoprivrednog $i$ šumskog bilja. Službeni list SFRJ, No. 38, 1980 and No. 82, 1990.

29. Zakon o zaštiti sorti poljoprivrednog i šumskog bilja, Službeni list SRJ, No. 28, 2000 and Službeni glasnik Republike Srbije, No. 101, 2005.

30. Zakon o zaštiti prava oplemenjivača biljnih sorti, Službeni glasnik Republike Srbije No. 41, 2009 and No. 88, 2011. 


\title{
PRAVNA ZAŠTITA NOVIH BILJNIH SORTI U REPUBLICI SRBIJI
}

\author{
Nadežda Ljubojev ${ }^{16}$, Marijana Dukić Mijatović17 ${ }^{17} \check{Z ̌ e l j k o ~ V o j i n o v i c ́ 18 ~}^{18}$
}

\begin{abstract}
Apstrakt
Opšte prihvaćena je zaštita novih biljnih sorti kao oblik intelektualne svojine. Radi se o sui generis pravnoj zaštiti koju u okviru prava industrijske svojine ostvaruju stvaraoci novih, distinktivnih, stabilnih $i$ homogenih biljnih sorti, označenih sortnom oznakom, ali u svetu postoji tendencija patentne zaštite. Osnovne odlike ove pravne zaštite su isključivost $i$ samostalnost $u$ odnosu na pravni režim ustanovljen za stavljanje sadnog materijala $u$ privredni promet. Cilj ovog rada je da sagleda pravne posledice i da odgovore na pojedina pitanja koja se tiču zaštite intelektualne svojine u ovoj oblasti. Korišćene su istorijsko-pravna i normativno-pravna metoda za razmatranje istorijskog razvoja pravne zaštite oplemenjivača biljaka i analize pozitivnog prava u ovoj oblasti u Republici Srbiji u okviru harmonizacije prava sa međunarodnim pravom i pravom Evropske unije.
\end{abstract}

Ključne reči: zaštita, biljne sorte, sui generis, patentno pravo, Republika Srbija.

16 Vanredni profesor, dr Nadezda Ljubojev, Univerzitet u Novom Sadu, Tehnički fakultet "Mihajlo Pupin”, Ulica Đure Đakovića bb, 23000 Zrenjanin, Republika Srbija, Telefon: +381 2355 0520, E-mail: nadezdaljubojev@gmail.com

17 Redovni profesor, dr Marijana Dukić-Mijatović, Univerzitet Privredna akademija, Pravni fakultet za ekonomiju i pravosuđe, Novi Sad, 21000 i Univerzitet u Novom Sadu, Ekonomski fakultet u Subotici, Segedinski put br. 9-11 24000 Subotica, Republika Srbija, Telefon: +381 63542093 , E-mail: marijana.dukic.mijatovic@gmail.com

18 Docent, dr ŽeljkoVojinović, Univerzitet u Novom Sadu, Ekonomski fakultet u Subotici, Segedinski put br. 9-11 24000 Subotica, Republika Srbija, Telefon: +381 6488326 00, E-mail: zv@inbajmok.com. 